\title{
Penggunaan Dekok Daun Kersen (Muntingia calabura L.) sebagai Teat Dipping Terhadap Persentase Penurunan California Mastitis Test dan Total Plate Count Air Susu
}

\author{
E. Giantara ${ }^{1}$, T. Akhdiat ${ }^{2 *}$, H. Permana ${ }^{2}$, N. Widjaja ${ }^{2}$ \\ ${ }^{1}$ Staff D dan J Scott Farm, New Zealand \\ ${ }^{2}$ Program Studi Peternakan, Fakultas Pertanian, Universitas Bandung Raya, Bandung 40272 \\ Dikirim 23 Juli 2018; Diterima 21 Maret 2019
}

\begin{abstract}
ABSTRAK
Penelitian bertujuan untuk mengetahui sejauh mana pengaruh penggunaan dekok daun kersen sebagai bahan teat dipping terhadap persentase penurunan california mastitis test dan total plate count pada air susu sapi yang paling efektif. Model penelitian ini adalah eksperimen menggunakan Rancangan Acak Lengkap (RAL) dengan 4 perlakuan yaitu, perlakuan teat dipping tanpa menggunakan dekok daun kersen (K0), perlakuan teat dipping menggunakan dekok daun kersen konsentrasi 45\% (K1), 50\% (K2), 55\% (K3). Setiap perlakuan diulang 6 kali. Peubah yang diamati yaitu persentase penurunan california mastitis test (CMT) dan uji total plate count (TPC) air susu sapi. Data yang diperoleh di analisis menggunakan sidik ragam, apabila terdapat pengaruh perlakuan di lanjutkan uji jarak berganda duncan's. Penelitian ini menyimpulkan bahwa penggunan dekok daun kersen berpengaruh terhadap persentase penurunan california mastitis test dan jumlah bakteri susu pada uji total plate count, penggunaan dekok daun kersen dosis 55\% menunjukkan hasil yang paling efektif dibandingkan dengan perlakuan lainya.
\end{abstract}

Kata kunci: Daun kersen, Teat dipping, CMT, TPC

\section{An Application of Muntingia calabura L. Leaves Extraction as Teat Dipping Against California Mastitis Test And Total Plate Count Test in Dairy Milk}

\begin{abstract}
This study in an experimental research using a Completely Randomized Design with 4 treatments, namely: Treat without dipping $0 \%$ of Muntingia calabura L. leaves extraction (KO), Dipping with consentration $45 \%$ of Muntingia calabura L. leaves extraction (K1), 50\% (K2), and 55\% (K3). All the treatments are repeted 6 times. The observed variables of this research are presence or absence of clotting milk that has treated mixed with reagent, and wether or not the decline number of bacteria in dairy milk that given the treatment. The data aquired during the process were analyzed using analysis of variance, if there have a significant effect, analysis continued with Duncan's Multiple Range Test. The study concluded that an application of Muntingia calabura L. Leaves Extraction has an effect against California Masitis Test and Total Plate Count Test in dairy milk, an application 55\% of Muntingia calabura L. leaves extraction is more effective than other treatments.
\end{abstract}

Keywords: Muntingia calabura L. leaves extraction, Teat dipping, CMT, TPC

\section{PENDAHULUAN}

Mastitis (radang ambing) merupakan radang infeksi, berlangsung secara akut, subakut maupun kronik, ditandai dengan kenaikan sel di dalam susu, perubahan fisik maupun susunan susu dan disertai atau tanpa disertai perubahan patologis atas kelenjarnya sendiri (Subronto, 2008). Penyebab utama mastitis pada sapi adalah kuman-kuman Streptococcus agalactie, Str. dysgalactie, Str. uberis dan Staphylococcus aureus. Penyakit mastitis subklinis sangat berdampak pada produksi dan kualitas susu yang dihasilkan sehingga akan mempengaruhi tingkat pendapatan peternak. Faktor penting yang mempengaruhi penyebaran mastitis pada sapi perah adalah terdapat mikroorganisme patogen dalam kuartir yang terinfeksi (Sudarman, 2017).

Susu adalah cairan yang keluar dari ambing sapi laktasi yang diperoleh melalui proses pemerahan. Susu mengandung banyak sekali nutrisi yang diperlukan oleh manusia juga mikroorganisme. Air dan bahan

*Penulis Korespondensi: Tedi Akhdiat

Alamat: Jl. Banten 11 Kota Bandung 40272

E-mail: akhdiatbdg@yahoo.com kering adalah dua komponen dalam susu. Bahan kering pada susu terdiri dari bahan kering tanpa lemak (BKTL), lemak, dan vitamin (A, D, E, K). Protein, laktosa (gula susu), mineral, vitamin B dan C, gas, enzim dan nitrogen bukan protein merupakan bagian dari bahan kering tanpa lemak.

Susu yang baik adalah susu yang tidak ditambah atau dikurangi sesuatu apapun yang dihasilkan dari pemerahan baik secara manual menggunakan tangan atau menggunakan mesin perah secara kontinyu. Salah satu parameter penentuan kualitas susu adalah dengan melihat kandungan bakteri yang terkandung dalam susu. Bakteri dalam susu dapat merusak dan mengubah sifat kimia, fisik, dan organoleptik susu. Jumlah maksimum bakteri pada susu menurut SNI (2011), adalah 1 x $10^{6} \mathrm{CFU} / \mathrm{mL}$. Kualitas susu sapi perah di Indonesia masih di bawah standar untuk keperluan konsumi atau industri dengan jumlah total plate count masih diatas satu juta per mililiter susu (Puspitasari, 2013). Semakin tinggi jumlah bakteri yang terkandung di dalam susu, menunjukkan bahwa susu tersebut rusak. Bakteri yang terkandung di dalam susu tidak semuanya baik untuk kesehatan, seperti bakteri $E$ coli yang bisa membahayakan tubuh manusia. Mutu mikroorganisme 
suatu bahan pangan ditentukan dari jumlah mikroorganisme yang terkandung dalam pangan tersebut. Daya simpan susu salah satunya ditentukan oleh kandungan mikroorganisme.

Kebersihan pada proses pemerahan adalah salah satu cara yang efektif mengurangi jumlah bakteri dalam susu, karena keadaan lingkungan yang kurang bersih dapat mempermudah terjadinya pencemaran. Kontaminasi susu dapat berasal dari alat-alat, udara, air, pemerah itu sendiri, faeces, ambing, dan debu. Cara lain yang juga sama efektifnya adalah dengan melakukan manajemen yang baik selama proses pemerahan. Teat dipping adalah manajemen yang baik yang bisa dilakukan untuk mengurangi jumlah bakteri dalam susu, juga dapat mengurangi jumlah kejadian mastitis.

Perlakuan teat dipping terhadap puting sapi dapat menurunkan jumlah bakteri dan jumlah sel somatik pada susu karena dapat menghambat masuknya bakteri ke dalam ambing. Bakteri yang masuk ke dalam ambing sapi sering terjadi setelah pemerahan, dikarenakan lubang puting setelah pemerahan terbuka, sehingga bakteri mudah sekali masuk ke dalam ambing. Teat dipping dilakukan setelah pemerahan selesai diharapkan dapat meminimalisir masuknya bakteri kedalam ambing (Swadayana et al., 2012) Kersen (Muntingia calabura L) yaitu daunnya tampak selalu hijau (evergreen), sepanjang tahun berbuah dan tumbuh. Pohon kersen yang daunnya rindang saat ini hanya dimanfaatkan sebagai tanaman peneduh di pinggir jalan. Senyawa-senyawa aktif dalam daun kersen berupa flavonoid, tannin, dan saponin merupakan senyawa utama yang memiliki kemampuan membunuh maupun menghambat pertumbuhan bakteri. Sasaran utamanya adalah bagian dinding sel.

Penggunaan dekok daun kersen sebagai cairan antibakteri untuk keperluan teat dipping sangat mungkin untuk dilakukan. Penggunaan dekok daun kersen yang terbuat dari 500 gram daun kersen ditambah 500 mililiter air $(50 \%)$ memberikan daya hambat mendekati larutan iodium (Maghriby et al., 2003). Dekok daun kersen dengan konsentrasi 50\% mempunyai kemampuan yang setara dengan iodium, karena dapat menghambat pertumbuhan bakteri Escherichia coli pada kasus mastitis (Gunawan et al., 2014).

Mekanisme daya hambat bakteri oleh senyawa antibakteri disebabkan oleh faktor-faktor, antara lain peningkatan permeabilitas membran sel yang menyebabkan kehilangan komponen penyusun sel, gangguan pada senyawa penyusun dinding sel, kerusakan fungsi material genetik, dan in-aktivasi enzim. Menurut Damayanti (2007) penggunaan antiseptik pada puting sapi setelah proses pemerahan dapat menurunkan jumlah bakteri sebesar $48 \%$. Teat dipping menggunakan bahan herbal mampu menurunkan skor mastitis subklinis meskipun belum mampu menyamai kemampuan iodium $10 \%$ (Lisholihah et al., 2014).

Teat dipping sudah diakui diberbagai negara pengembang peternakan, bahwa dapat meminimalisir terjadinya kejadian mastitis juga menurunkan jumlah kandungan bakteri dalam susu. Pengujian CMT adalah salah satu cara tercepat deteksi mastitis sehingga penanganan mastitis dapat dilakukan sedini mungkin. Pengujian TPC yang dilakukan di berbagai laboratorium susu bertujuan untuk meningkatkan kualitas susu sehingga susu yang diproduksi layak dikonsumsi oleh manusia.

\section{MATERI DAN METODE}

Materi penelitian adalah sapi perah Frisian Holstein (FH) laktasi sebanyak 24 ekor, dekok daun kersen, reagent CMT, air susu sapi. Alat yang digunakan: stopwatch, gelas ukur, botol sampel susu, botol teat dipping, paddle CMT, waterbath, termos es. Rancangan percobaan yang digunakan adalah Rancangan Acak Lengkap (RAL) Pola Searah dengan 4 perlakuan berdasarkan tingkat konsentrasi dekok daun kersen. Setiap perlakuan diulang 6 kali.

\section{Analisis Data}

Data yang di dapat dianalisis menggunakan sidik ragam mengacu pada Steel dan Torrie (1991). Bila ada pengaruh perlakuan dilanjutkan dengan uji wilayah berganda Duncan's.

\section{HASIL DAN PEMBAHASAN}

\section{Pengaruh Dekok Daun Kersen terhadap California Mastitis Test (CMT) dan Total Plate Count (TPC)}

CMT melihat ada tidaknya perubahan kekentalan pada susu, kemudian penilaian berdasarkan nilai interprestasi yang mana nilai tersebut dihitung berapa persen penurunannya. Hasil CMT pada masing-masing perlakuan dapat dilihat pada Tabel 1 .

Tabel 1. Rataan persentase penurunan CMT dan TPC pada masing-masing perlakuan selama

\begin{tabular}{ccccc}
\hline \hline \multirow{2}{*}{$\begin{array}{c}\text { Parameter yang } \\
\text { Diamati }\end{array}$} & $\mathrm{K} 0$ & $\mathrm{~K} 1$ & $\mathrm{~K} 2$ & $\mathrm{~K} 3$ \\
\cline { 2 - 5 } & $0,71^{\mathrm{c}}$ & $0,71^{\mathrm{c}}$ & $2,12^{\mathrm{b}}$ & $4,62^{\mathrm{a}}$ \\
\hline $\begin{array}{c}\text { Rataan Penurunan } \\
\text { CMT (\%) } \\
\text { Rataan Penurunan } \\
\text { TPC (\%) }\end{array}$ & $0,71^{\mathrm{c}}$ & $3,59^{\mathrm{b}}$ & $3,42^{\mathrm{b}}$ & $4,81^{\mathrm{a}}$ \\
\hline
\end{tabular}

${ }^{\mathrm{abc}}$ Superskrip yang berbeda pada baris yang sama menunjukkan perbedaan yang nyata $(\mathrm{P}<0,05)$, ns (non signifant $)=$ berbeda tidak nyata $(\mathrm{P}>0,05) . \mathrm{K} 0=$ Tanpa menggunakan dekok daun kersen, $\mathrm{K} 1=$ Dekok daun kersen $45 \%, \mathrm{~K} 2=$ Dekok daun kersen $50 \%$, dan K3 = Dekok daun kersen $55 \%$.

Data Tabel 1 diatas dapat dilihat rataan persentase penurunan CMT terbesar ditunjukan pada K3 (4,62\%) dan terendah pada perlakuan K0 $(0,71 \%)$ dan $\mathrm{K} 1$ $(0,71 \%)$ semakin tinggi persentase dekok daun kersen yang digunakan semakin tinggi penurunan CMT. Menurut Gunawan et al. (2014) bahwa daun kersen dapat digunakan sebagai antibakteri karena mengandung senyawa tannin, flavonoid, dan saponin. Antibakteri adalah zat yang dapat menghambat pertumbuhan bakteri dengan cara merusak dinding sel 
dan mengganggu permeabilitas sehingga sintesis protein dan asam laktat terganggu. Hasil sidik ragam menunjukkan bahwa perlakuan berpengaruh sangat nyata $(\mathrm{P}<0,01)$ terhadap CMT. Rataan persentase penurunan CMT pada K3 nyata lebih besar jumlahnya dari rataan persentase penurunan $\mathrm{CMT}$ pada $\mathrm{K} 2$, $\mathrm{K} 1$, dan K0. Hal ini diduga karena pada K3 (55\%) persentase dekok daun kersen yang digunakan lebih tinggi dibandingkan $\mathrm{K} 2(50 \%), \mathrm{K} 1(45 \%)$, dan $\mathrm{K} 0$ (0\%) sehingga kandungan senyawa anti bakteri (saponin, flavonoid, dan tannin) dalam K3 lebih banyak dan mampu menghambat masuknya mikroorganisme kedalam saluran ambing. Sesuai pendapat Aprilia et al. (2016) proses mastitis dimulai dengan masuknya mikroorganisme ke dalam kelenjar melalui lubang puting. Lubang puting berfungsi untuk menahan infeksi kuman. Pada dasarnya kelenjar mammae sudah dilengkapi perangkat pertahanan, sehingga air susu tetap steril. Tingkat pertahanan kelanjar mammae mencapai titik terendah saat sesudah pemerahan, karena lubang puting masih terbuka beberapa saat, sel darah putih, antibodi serta enzim juga habis ikut terperah. Pencegahan terhadap mastitis dapat dilakukan dengan teat dipping. Perlakuan teat dipping menurunkan jumlah sel somatik pada sapi perah. Sel somatik di dalam air susu terutama terdiri dari leukosit dan beberapa dari sel epitel. Peningkatan jumlah sel somatik di dalam air susu menunjukan adanya gangguan di dalam kelenjar susu, terutama peradangan pada kelenjar susu akibat infeksi mikroorganisme Mahardika (2016). Menurut Swadayana et al., (2012) bahwa teat dipping ke dalam larutan desinfektan digunakan untuk melapisi atau menutup saluransaluran susu pada puting agar tidak terkontaminasi bakteri dari udara sekitar yang dapat menyebabkan kualitas susu menurun dan terjadinya peradangan pada ambing. Dengan melakukan teat dipping maka dapat menurunkan jumlah bakteri serta angka peradangan juga menurun. Rataan persentase penurunan CMT untuk K0 dan $\mathrm{K} 1$ berbeda tidak nyata, menunjukkan bahwa penggunaan dekok daun kersen $0 \%$ dan $45 \%$ tidak begitu berpengaruh terhadap penurunan CMT. Hal ini di duga karena kandungan anti bakteri dalam dekok daun kersen belum mampu menghambat masuknya mikroorganisme ke dalam saluran ambing.

TPC adalah menghitung jumlah bakteri dilakukan pada semua koloni yang tumbuh pada nutrient agar dengan menggunakan rumus :

Jumlah bakteri permililiter $=$ Jumlah koloni $X \frac{1}{\text { Faktor pengenceran }}$

Data pada Tabel 1 dapat dilihat rataan persentase penurunan Uji TPC pada susu sapi terbesar ditunjukkan pada K3 $(4,18 \%)$ dan terendah K0 $(0,71 \%)$, semakin tinggi persentase dekok daun kersen semakin tinggi penurunan jumlah bakterinya. Hasil sidik ragam memperlihatkan bahwa penggunaan dekok daun kersen berpengaruh sangat nyata $(\mathrm{P}<0,01)$ terhadap uji TPC. Rataan persentase penurunan rataan persentase bakteri dengan uji TPC air susu pada K3 nyata lebih besar jumlahnya dibandingkan rataan penurunan persentase bakteri dengan uji TPC pada K2, K1 dan K0. Hal ini diduga kandungan anti bakteri dalam dekok daun kersen seperti saponin, flavonoid, dan tannin pada K3 lebih tinggi sehingga bekerja lebih efektif dalam membunuh bakteri di sekitar ambing dan puting susu, sedangkan K0 tidak dilakukan pencelupan puting sehingga penurunan rataan persentase bakterinya lebih sedikit dari K3, K2 dan K1. Sesuai pendapat Noorhamdani et al. (2010) saponin sangat efektif dalam menghambat atau bahkan mematikan bakteri di sekitar puting sapi. Flavonoid memberikan efek anti bakteri antara lain: (i) menghambat fungsi membran sitoplasma; (ii) menghambat sintesis asam nukleat, (iii) menghambat aktivitas bakteri dengan jalan menghambat metabolisme energi, (iv) menghambat konsumsi oksigen dengan jalan menggangu rantai transport elektron respirasi. Sejalan dengan pendapat Hidayaningtyas (2008) tanin merupakan senyawa turunan flavonoid yang dapat merusak komponen protein dari bakteri.

Menurut Rachmawati et al. (2009), tannin merupakan salah satu anti bakteri yang terkandung di dalam ekstrak daun kersen yang bisa dengan mudah masuk kedalam sel bakteri dan mengkoagulasi protoplasma sel bakteri, dan mengakibatkan sel tidak dapat melakukan aktivitas hidup dan pertumbuhanya terhambat atau bahkan mati. Selanjutnya Mahardika et al. (2014) menyatakan senyawa tannin pada daun kersen dapat menghambat aktivitas enzim protease, menghambat enzim pada transport selubung sel bakteri, destruksi atau inaktivasi fungsi materi genetik, selain itu tannin juga mampu mengkerutkan dinding sel, akibat terganggunya permeabilitas sel, maka sel bakteri tersebut tidak dapat melakukan aktivias hidup sehingga pertumbuhanya terhambat atau bahkan mati. Sedangkan menurut Permatasari et al. (2013) saponin termasuk dalam kelompok antibakteri yang dapat mengganggu permeabilitas membran sel mikroba, mengakibatkan kerusakan membran sel dan menyebabkan keluarnya berbagai komponen penting dari dalam sel mikroba seperti protein, asam nukleat, nukleotida.

Penurunan persentase jumlah bakteri Uji TPC pada K2 dan K1 berbeda tidak nyata, menunjukkan bahwa penggunaan dekok daun kersen $45 \%$ dan $50 \%$ tidak begitu berpengaruh terhadap penurunan persentase bakteri, hal ini di duga kandungan anti bakteri pada $\mathrm{K} 2$ dan $\mathrm{K} 1$ relatif sama.

\section{KESIMPULAN}

Berdasarkan hasil penelitian yang dilakukan di daerah Sumedang Jawa Barat dapat disimpulkan bahwa penggunaan dekok daun kersen berpengaruh terhadap persentase penurunan california mastitis test dan jumlah bakteri pada susu pada uji total plate count sedangkan penggunaan dekok daun kersen dosis 55\% 
menunjukkan hasil yang paling efektif dibandingkan dengan perlakuan lainya.

\section{DAFTAR PUSTAKA}

Aprilia, P. R., S. A. B. Santoso dan D. W. Harjanti. 2016. Jumlah Staphylococcus aureus dan kandungan nutrien susu akibat dipping puting menggunakan ekstrak daun belimbing wuluh (Averrhoa bilimbi Linn) pada sapi perah penderita mastitis subklinis. Jurnal Ilmu-Ilmu Peternakan 26(1): 43-51.

Damayanti, L. 2007. Pengaruh teat spray dengan menggunakan jus buah mengkudu (Morinda citrifolia $L$ ) dalam berbagai konsentrasi terhadap hasil uji CMT dan TPC pada Sapi Perah. Skripsi. Fakultas Peternakan. Universitas Brawijaya. Malang.

Gunawan, A. D., Sarwiyono dan S. Puguh. 2014. Resistibility of cherry water extract leaves (Muntingia calabura l) toward of escherichia coli growth that causes mastitis desease in dairy cows. Jurnal Brawijaya University. http://fapet.ub.ac.id/wp-content/uploads/2014/01/ Daya-Hambat-Dekok-Daun-Kersen-MuntingiaCalabura-L.-Terhadap-Pertumbuhan-Escherichia -Coli-Penyebab-Penyakit-Mastitis-Sapi-Perah .pdf. Diakses 01 Januari 2017.

Hidayaningtyas, P. 2008. perbandingan efek antibakteri seduhan daun sirih (piper batle linn) terhadap Streptococcus mutans pada waktu kontak dan konsentrasi yang berbeda. http://eprints.undip.ac.id/24283/1/Prima.pdf. Diakses 09 Februari 2017.

Lisholihah. I., Sarwiyono dan S. Puguh. 2014. Pengaruh teat dipping daun beluntas (Pluchea indica less) terhadap kualitas susu berdasarkan california mastitis test dan uji reduktase. Jurnal. Universitas Brawijaya. http://fapet.ub.ac.id/wpcontent/uploads/2014/06/JURNAL_Iftitah-

Lisholihah_105050113111023.pdf . Diakses 20 Desember 2016.

Maghriby H. R., Sarwiyono dan P. Surjowardjoyo. 2014. Daya hambat dekok daun kersen (muntingia calabura 1.) terhadap pertumbuhan bakteri grampositif staphylococcus aureus dan gram-negarif escherichia coli penyebab penyakit mastitis pada sapi perah. Jurnal Fakultas Peternakan. Jurnal. Universitas Brawijaya. http://fapet.ub.ac.id/wpcontent/uploads/2014/01/DAYA-HAMBAT-

DEKOK-DAUN-KERSEN-Muntingia-calaburaL.-TERHADAP-PERTUMBUHAN-BAKTERIGRAM-POSITIF-Staphylococcus-aureus-DANGRAM-NEGATIF-Escherichia-coliPENYEBAB-PENYAKIT-MASTITIS-PADASAPI-PERAH.pdf . Diakses 16 Desember 2016

Mahardika, H. A., Sarwiyono dan P. Surjowardjojo. 2014. Ekstrak metanol daun kersen (Muntingia calabura l.) sebagai antimikroba alami terhadap bakteri Stapylococcus aureus penyebab mastitis subklinis pada sapi perah. Jurnal Teknik Tropika 15(2): 15-22.

Mahardika, H. A. 2016. Pengaruh suhu air pencucian ambing dan teat dipping terhadap jumlah produksi, kualitas dan jumlah sel somatik susu pada peternakan sapi perah Fresian Holstein. Buletin Peternakan 40(1): 11-19.

Noorhamdani, Hermawan, dan D. Rosalia. 2010. Uji ekstrak daun kersen (Muntingia calabura l.) sebagai antibakteri terhadap Metchicillin resistant aphylococcus aureus (MRSA) secara in vitro. http://old.fk.ub.ac.id//id/filedownload/kedokteran /Dian\%20Rosalia.pdf. Diakses 3 Februari 2017.

Permatasari, G. A. A., I. N. K. Besung dan H. Mahatmi. 2013. Daya hambat perasan daun sirsak terhadap pertumbuhan bakteri Escherichia coli. Indonesia Medicus Veterinus 2(2): 162-169.

Puspitasari, R. 2013. Susu sapi: kualitas masih di bawah standard kebutuhan industri. http://industri.bisnis.com/read/20130215/99/1364 52/susu-sapi-kualitas-masih-di-bawah-standardkebutuhan-industri. Di Akses 13 Desember 2016.

Rachmawaty, F. J., Citra, D. A., B. Nirwani, T. Nurmasitoh dan Bowo, E. T. 2009. Manfaat sirih ( piper crocatum ) sebagai anti bakterial terhadap gram positif dan gram negatif. Jurnal Kedokteran dan Kesehatan Indonesia 1(1): 1-10.

SNI. 2011. Standar nasional indonesia: susu segar bagian 1. ICS 67.100.01. http://sisni.bsn.go.id. Diakses 6 Mei 2016

Steel, R. G. D. dan J. H . Torrie. 1991. Prinsip dan Prosedur Statistika. Penerjemah Bambang Sumantri. Gramedia Pustaka. Jakarta.

Swadayana, A., P. Sambodho dan C. Budiarti. 2012. Total bakteri dan $\mathrm{pH}$ susu akibat lama waktu dipping puting kambing peranakan ettawa laktasi. Animal Agriculture Journal 01(01): 12-21.

Swartz. 2006. Resistensi atau kepekaan terhadap mastitis pada sapi, kambing atau domba bersifat menurun. https://ariputuamijaya.wordpress.com/ 2011/12/1/mastitis/. Diakses 20 Januari 2017. 